\title{
ERBIUM LASERS IN PERIODONTOLOGY
}

\author{
Mariya Miteva, Elitsa Sabeva, Irena Georgieva, Ivailo Hristov \\ Department of Periodontology and Dental Implantology, Faculty of Dental Medicine, \\ Medical University of Varna
}

\begin{abstract}
There are many advantages to using lasers in periodontal therapy, including better visualization of cutting, patient acceptance, and detoxification of a periodontal pocket. Other advantages are less invasive surgery to gain access, minimal wound contraction and scarring. Many of these concepts of laser therapy are positive, although others still require research. There are clearly many favorable applications for lasers in periodontal therapy but further studies are necessary to determine in which procedures laser therapy can be best applied.
\end{abstract}

Keywords: erbium lasers, periodontal therapy

\section{INTRODUCTION}

Erbium lasers have two different wavelengths: Er, Cr: YSGG (erbium, chromium:yttrium-scandium-gallium-garnet $2790 \mathrm{~nm}$ ) and Er: YAG (erbiumdoped yttrium aluminium garnet laser $2940 \mathrm{~nm}$ ). They have high affinity for hydroxyapatite and high water absorption. Therefore, they are a good choice for treating hard tissues (1). Apart from hard tissues, erbium lasers can be used to remove soft tissues because the soft tissue contains a high percentage of water (2).

\section{Effect on Cement}

Some of the earlier studies (3) on the use of Er: YAG lasers on the root cement show detrimental effects, such as heat-induced cracks and the formation

Address for correspondence:

Mariya Miteva

Faculty of Dental Medicine

84 Tsar Osvoboditel Blvd

9000 Varna

e-mail:maria.miteva@mu-varna.bg

Received: April 26, 2017

Accepted: May 29, 2017 of craters, despite the presence of water cooling. Other authors (4) noted greater cement loss and residual root roughness when SRP with Er: YAG laser was compared with ultrasonic or manual instrumentation. Under a scanning electron microscope, total cement removal was observed in $22.5 \%$ of the lasertreated teeth, compared with $12.5 \%$ of the teeth treated with SRP alone. These negative results are confirmed in vitro when the energy exceeds $50 \mathrm{~mJ} /$ pulse (5), although the adverse temperature effects decrease with water irrigation (6). The water jet can reduce the pulp wall temperature by $2.2^{\circ} \mathrm{C}$. Even with relatively low energy $(60 \mathrm{~mJ})$, the Er: YAG lasers remove calculus and/or cement, and the cement penetration increases significantly at $150 \mathrm{~mJ}(7)$. Up to $386.12 \mu \mathrm{m}$ of tooth cement is removed by laser at 100 mJ (7), although Aoki et al. (8) disagreed with these findings and reported a maximum removal of cement with a $140 \mu \mathrm{m}$ laser.

Water surface cooling is of utmost importance as it prevents heat-induced surface changes and prevents the pulp from the rising temperature by irradiating the root surface $(9,10,11)$. Achieving adequate water cooling in deeper periodontal pockets is probably unsatisfactory. Most studies showing heat-induced surface changes or lack of them use SEM. SEM is a microscopic surface study and cannot read the

Scripta Scientifica Medicinae Dentalis, vol. 3, No 1, 2017, pp. 7-11 
changes below the surface. One study shows subsurface changes of dentine after cement ablation with Er: YAG laser at parameters 60,100 and $180 \mathrm{~mJ}$. The heat changes spread in the dentine from 255 to $611 \mu \mathrm{m}$ measured from the surface and appear irrespective of the radiation level (12). As with other laser wavelengths, the choice of parameters is paramount when considering tissue damage.

In this regard, Crespi et al. (13) demonstrated by their in vitro study that the use of a defocused Er: YAG laser in a non-contact mode effectively removes the calculus with minimal cement damage. Several studies highlight the relationship between the increase in power and energy density, and the increased removal of root structure $(9,10)$ and the number and depth of induced surface craters $(4,10)$.

According to Qu CN et al. (14) Er, Cr: YSGG laser can affect the microstructure of the cement of both periodontally affected teeth and healthy teeth. The irradiation with it results in the decrease of the presence of a smear layer and increased roughness of the root surface.

\section{Effect on Fibroblasts}

It has been proved that lasers can favor the adhesion of fibroblasts to the root surfaces (15). Moreover, lasers can increase DNA synthesis, enhance collagen and procollagen production and increase the rate of cell proliferation.

In addition, in vitro fibroblast adhesion studies show that the obtained root surface is comparable to that obtained after SRP $(16,17)$.

Pourzarandian et al. demonstrated that Er: YAG laser irradiation stimulates the proliferation of human fibroblasts through platelet-derived growth factor (PDGF) production (18). There have been studies that indicate that Er: YAG laser irradiation gets its gingival fibroblast proliferation stimulating effect through the production of PGE2 by the expression of COX-2 (19).

When exposed to a laser, the fibroblasts are polarized and form bundles in different directions.

A study of Talebi-Ardakani et al. indicated that both Er: YAG and Er, Cr: YSGG lasers lead to a significant increase in gingival fibroblast proliferation compared with control groups at 10 and 30 seconds (20).
The results of an in vitro study by Hakki SS et al. (21) showed that the Er, Cr: YSGG laser used in short-pulse is more promising in terms of the attachment and orientation of the periodontal fibroblasts than its use in long-pulse or manual instrumentation with Gracey Curettes.

\section{Effect on Root Morphology}

Gašpric and Skalerič (22) showed that the variations in applied energy $(60 \mathrm{~mJ}, 80 \mathrm{~mJ}$ and $100 \mathrm{~mJ})$ lead to different root morphology. At $60 \mathrm{~mJ}$, single craters were observed without deposits of molten minerals and exposed dentin tubules. At $80 \mathrm{~mJ}$, numerous merging craters and $100 \mathrm{~mJ}$ large ablation defects were observed.

When Er: YAG lasers are used at values ranging from 25 to $100 \mathrm{~mJ} / \mathrm{sec}$ on the root surface in vitro, a 15-micron degraded layer of cement is observed without the presence of Sharp fiber (23). However, when it is used in vivo, there is a smooth root surface even at higher values (24).

Tip angulation is the main factor influencing the roughness of the root surface. Folwaczny et al. (25) evaluated the effect of different angulation (15, $30,45,60,90$ degrees) on the removal ability and roughness of the dental root. The control group consists of root surfaces, curette-guided only. The authors did not report a statistically significant difference in roughness between the two groups. Also, there are no differences in the removal of calculus at the various angulations.

When used with low energy and water cooling, most of the studies show little or no thermal damage and a smooth root surface $(11,26)$.

Mishra and Prakash (27) evaluated the effect of manual instrumentation, ultrasonic scaling and Er: YAG laser irradiation on the formation of a smear layer on the root surface. Most of the areas that were treated with hand tools (66.7\%) and ultrasonic scaling $(80 \%)$ were coated with a smear layer, while lack of it was observed in $60 \%$ of the laser-treated areas.

Oliveira GJ et al. (28) demonstrated that surfaces irradiated with Er: YAG and Er, Cr: YSGG lasers show similar morphological characteristics including root surface roughness, smear layer absence, open dentin tubules and no thermal damage. These observations are also confirmed by other in vitro 
Mariya Miteva, Elitsa Sabeva, Irena Georgieva, Ivailo Hristov

studies evaluating the dentin morphology after irradiation with Er: YAG $(24,29)$ and Er, Cr: YSGG $(30)$.

Blomlöf et al. (31) showed that ultrasonic debridement leads to smooth surfaces coated with a smear layer containing debris, contaminated cement, bacterial endotoxin and subgingival plaque, while Er: YAG treated surfaces are rough and clean at a microstructural level. Such morphological roughness favors the adhesion and proliferation of fibroblasts (32).

\section{Clinical Effects}

Laser debridement as a monotherapy, compared with laser debridement in addition to SRP, shows that most clinical parameters are similarly improved and maintained for more than one year (33). A group of researchers (34) compared laser treatment with SRP as monotherapy and received favorable results for laser-treated teeth. Concerning the pocket depth and clinical attachment level, both groups showed statistically significant improvement after treatment. For the clinical attachment level, the laser-treated group showed a greater improvement, but the difference was not statistically significant. A two-year prospective study by the same group of authors (35) confirms the beneficial results from laser treatment. The beneficial effects of the Er: YAG laser in surgical periodontal therapy were observed in a study by Sculean et al. (36). Sculean et al. (37) compared the use of a laser alone with ultrasound debridement and found that both treatments had comparable calculus removal performance, although the laser was less effective than ultrasound debridement. No differences in clinical parameters were reported.

One study (38) of two different treatment methods (Er: YAG laser against sound debridement) of persistent periodontal pockets also showed no significant differences in clinical and microbiological results in the study groups.

Yilmaz et al. (39) showed that there were statistically significant improvements in clinical attachment level and in the reduction of pocket depth at the sites treated with the Er: YAG laser in addition to SRP, compared to sites treated only with SRP.

Kelbauskiene $\mathrm{S}$ et al. reported in their study that the use of the Er; Cr: YSGG laser as an adjunct to conventional SRP treatment results in significantly lower values of pocket depth over a 3-month period when compared to SRP alone (40).

\section{CONCLUSION}

The use of lasers in periodontology is still the subject of many studies. It is difficult to compare the numerous studies for the erbium lasers in relation to the parameters used. Considering the controversial study results, further research is needed to establish the effectiveness of erbium lasers.

\section{REFERENCES}

1. Harashima T, Kinoshita J, Kimura Y, Brugnera A, Zanin F, Pecora JD, Matsumoto K. Morphological comparative study on ablation of dental hard tissues at cavity preparation by Er:YAG and Er,Cr:YSGG lasers. Photomed Laser Surg. 2005;23(1):52-5. doi: 10.1089/pho.2005.23.52

2. Ishikawa I, Aoki A, Takasaki AA. Clinical application of erbium:YAG laser in periodontology. J Int Acad Periodontol. 2008;10(1):22-30.

3. Dostálová T, Jelínková $\mathrm{H}, \mathrm{Krejsã} \mathrm{O}, \mathrm{Hamal} \mathrm{H}$. Evaluation of the surface changes in enamel and dentin due to possibility of thermal overheating induced by Erbium:YAG laser radiation. Scanning Microsc. 1996;10(1):285-90; discussion 290-1.

4. Frentzen M, Braun A, Aniol D. Er:YAG laser scaling of diseased root surfaces. J Periodontol. 2002;73(5):524-30. doi: 10.1902/jop.2002.73.5.524

5. Aoki A, Ando Y, Watanabe H, Ishikawa I. In vitro studies on laser scaling of subgingival calculus with an erbium:YAG laser. J Periodontol. 1994;65(12):1097-106. doi: 10.1902/ jop.1994.65.12.1097

6. Sasaki KM, Aoki A, Ichinose S, Ishikawa I. Morphological analysis of cementum and root dentin after Er:YAG laser irradiation. Lasers Surg Med. 2002;31(2):79-85. doi: 10.1002/lsm.10074

7. Folwaczny M, Mehl A, Haffner C, Benz C, Hickel R. Root substance removal with Er:YAG laser radiation at different parameters using a new delivery system. J Periodontol. 2000;71(2):147-55. doi: 10.1902/jop.2000.71.2.147

8. Aoki A, Miura M, Akiyama F, Nakagawa N, Tanaka J, Oda S, et al. In vitro evaluation of Er:YAG laser scaling of subgingival calculus in comparison with ultrasonic scaling. J Periodontal Res. 2000;35(5):266-77. doi: $10.1034 / j .1600-0765.2000 .035005266 . x$ 
9. Schoop U, Moritz A, Maleschitz P, Goharkhay K, Kiuger W, Werisch J, et al. The impact of Er:YAG laser irradiation on root surfaces: An in vitro evaluation. J Oral Laser. 2001;1(1):35-41.

10. Schwarz F, Pütz N, Georg T, Reich E. Effect of an Er:YAG laser on periodontally involved root surfaces: an in vivo and in vitro SEM comparison. Lasers Surg Med. 2001;29(4):328-35. doi: 10.1002/lsm.1125

11. Theodoro LH, Haypek P, Bachmann L, Garcia VG, Sampaio JE, Zezell DM, et al. Effect of ER:YAG and diode laser irradiation on the root surface: morphological and thermal analysis. J Periodontol. 2003;74(6):838-43. doi: 10.1902/jop.2003.74.6.838

12. Folwaczny M, Benner KU, Flasskamp B, Mehl A, Hickel R. Effects of 2.94 microm Er:YAG laser radiation on root surfaces treated in situ: a histological study. J Periodontol. 2003;74(3):360-5. doi: 10.1902/ jop.2003.74.3.360

13. Crespi R, Romanos GE, Barone A, Sculean A, Covani U. Er:YAG laser in defocused mode for scaling of periodontally involved root surfaces: an in vitro pilot study. J Periodontol. 2005;76(5):686-90. doi: 10.1902/jop.2005.76.5.686

14. Qu CN, Kang J, Luan QX. Effects of Er, Cr: YSGG laser on the root surface of periodontitis and healthy teeth. Beijing Da Xue Xue Bao. 2016;48(1):71-5.

15. Maruyama H, Aoki A, Sasaki KM, Takasaki AA, Iwasaki K, Ichinose S, et al. The effect of chemical and/or mechanical conditioning on the Er:YAG laser-treated root cementum: analysis of surface morphology and periodontal ligament fibroblast attachment. Lasers Surg Med. 2008;40(3):211-22. doi: 10.1002/lsm.20609

16. Feist IS, De Micheli G, Carneiro SR, Eduardo CP, Miyagi S, Marques MM. Adhesion and growth of cultured human gingival fibroblasts on periodontally involved root surfaces treated by Er:YAG laser. J Periodontol. 2003;74(9):1368-75. doi: 10.1902/ jop.2003.74.9.1368

17. Schwarz F, Sculean A, Berakdar M, Szathmari L, Georg T, Becker J. In vivo and in vitro effects of an Er:YAG laser, a GaAlAs diode laser, and scaling and root planing on periodontally diseased root surfaces: A comparative histologic study. Lasers Surg Med 2003;32:359-366. doi: 10.1002/lsm.10179

18. Pourzarandian A, Watanabe H, Ruwanpura SM, Aoki A, Ishikawa I. Effect of low-level Er:YAG laser irradiation on cultured human gingival fibroblasts.
J Periodontol. 2005;76(2):187-93. doi: 10.1902/ jop.2005.76.2.187

19. Pourzarandian A, Watanabe H, Ruwanpura SM, Aoki A, Noguchi K, Ishikawa I. Er:YAG laser irradiation increases prostaglandin E production via the induction of cyclooxygenase- 2 mRNA in human gingival fibroblasts. J Periodontal Res. 2005;40(2):182-6. doi: 10.1111/j.1600-0765.2005.00789.x

20. Talebi-Ardakani MR, Torshabi M, Karami E, Arbabi E, Rezaei Esfahrood Z. In Vitro Study of Er:YAG and Er, Cr:YSGG Laser Irradiation on Human Gingival Fibroblast Cell Line. Acta Medica Iran. 2006;54(4):251-5

21. Hakki SS, Korkusuz P, Berk G, Dundar N, Saglam M, Bozkurt B, et al. Comparison of Er,Cr:YSGG laser and hand instrumentation on the attachment of periodontal ligament fibroblasts to periodontally diseased root surfaces: an in vitro study. J Periodontol. 2010;81(8):1216-25. doi: 10.1902/ jop.2010.090715

22. Gašpirc B, Skalerič U. Morphology, chemical structure and diffusion processes of root surface after Er:YAG and Nd:YAG laser irradiation. J Clin Periodontol 2001;28(6):508-516. doi: 10.1034/j.1600-051x.2001.028006508.x

23. Fujii T, Baehni PC, Kawai O, Kawakami T, Matsuda K, Kowashi Y. Scanning electron microscopic study of the effects of Er:YAG laser on root cementum. J Periodontol. 1998;69(11):1283-90. doi: 10.1902/jop.1998.69.11.1283

24. Eberhard J, Ehlers H, Falk W, Açil Y, Albers HK, Jepsen S. Efficacy of subgingival calculus removal with Er:YAG laser compared to mechanical debridement: an in situ study. J Clin Periodontol. 2003;30(6):511-8. doi: 10.1034/j.1600-051X.2003.00052.x

25. Folwaczny M, George G, Thiele L, Mehl A, Hickel R. Root surface roughness following Er:YAG laser irradiation at different radiation energies and working tip angulations. J Clin Periodontol. 2002;29(7):598-603. doi: 10.1034/j.1600-051X.2002.290703.x

26. Yamaguchi H, Kobayashi K, Osada R, Sakuraba E, Nomura T, Arai T, et al. Effects of irradiation of an erbium:YAG laser on root surfaces. J Periodontol.1997;68(12):1151-5. doi: 10.1902/ jop.1997.68.12.1151 
Mariya Miteva, Elitsa Sabeva, Irena Georgieva, Ivailo Hristov

27. Mishra MK, Prakash S. A comparative scanning electron microscopy study between hand instrument, ultrasonic scaling and erbium doped:Yttirum aluminum garnet laser on root surface: A morphological and thermal analysis. Contemp Clin Dent. 2013;4(2):198-205. doi: 10.4103/0976-237X.114881

28. Oliveira GJ, Theodoro LH, Marcantonio Junior E, Sampaio JE, Marcantonio RA. Effect of Er,Cr:YSGG and Er:YAG laser irradiation on the adhesion of blood components on the root surface and on root morphology. Braz Oral Res. 2012;26(3):256-62. doi: 10.1590/ S1806-83242012000300012

29. Theodoro LH, Garcia VG, Haypek P, Zezell DM, Eduardo Cde P. Morphologic analysis, by means of scanning electron microscopy, of the effect of Er: YAG laser on root surfaces submitted to scaling and root planing. Pesqui Odontol Bras. 2002;16(4):308-12. doi: 10.1590/ S1517-74912002000400005

30. de Oliveira GJ, Sampaio JE, Marcantonio RA. Effects of Er,Cr:YSGG laser irradiation on root surfaces for adhesion of blood components and morphology. Photomed Laser Surg. 2010;28(6):751-6. doi: 10.1089/pho.2009.2681

31. Blomlöf JP, Blomlöf LB, Lindskog SF. Smear removal and collagen exposure after non-surgical root planing followed by etching with an EDTA gel preparation. J Periodontol. 1996;67(9):841-5. doi: 10.1902/jop.1996.67.9.841

32. Babay N. Attachment of human gingival fibroblasts to periodontally involved root surface following scaling and/or etching procedures: a scanning electron microscopy study. Braz Dent J. 2001;12(1):17-21.

33. Schwarz F, Sculean A, Berakdar M, Georg T, Reich E, Becker J. Clinical evaluation of an Er:YAG laser combined with scaling and root planing for non-surgical periodontal treatment. A controlled, prospective clinical study. J Clin Periodontol. 2003;30(1):26-34. doi: 10.1034/j.1600-051X.2003.300105.x

34. Schwarz F, Sculean A, Georg T, Reich E. Periodontal treatment with an Er: YAG laser compared to scaling and root planing. A controlled clinical study. J Periodontol. 2001;72(3):361-7. doi: 10.1902/ jop.2001.72.3.361

35. Schwarz F, Sculean A, Berakdar M, Georg T, Reich E, Becker J. Periodontal treatment with an Er:YAG laser or scaling and root planing. A 2-year follow- up split-mouth study. J Periodontol. 2003;74(5):5906. doi: 10.1902/jop.2003.74.5.590

36. Sculean A, Schwarz F, Berakdar M, Windisch P, Arweiler NB, Romanos GE. Healing of intrabony defects following surgical treatment with or without an Er:YAG laser. J Clin Periodontol. 2004;31(8):604-8. doi: 10.1111/j.1600-051X.2004.00525.x

37. Sculean A, Schwarz F, Berakdar M, Romanos GE, Arweiler NB, Becker J. Periodontal treatment with an Er:YAG laser compared to ultrasonic instrumentation: a pilot study. J Periodontol. 2004;75(7):96673. doi: 10.1902/jop.2004.75.7.966

38. Ratka-Krüger P, Mahl D, Deimling D, Mönting JS, Jachmann I, Al-Machot E, et al. Er:YAG laser treatment in supportive periodontal therapy. J Clin Periodontol. 2012;39(5):483-9. doi: 10.1111/j.1600-051X.2012.01857.X

39. Yilmaz S, Algan S, Gursoy H, Noyan U, Kuru BE, Kadir T. Evaluation of the clinical and antimicrobial effects of the Er:YAG laser or topical gaseous ozone as adjuncts to initial periodontal therapy. Photomed Laser Surg. 2013;31(6):293-8. doi: 10.1089/pho.2012.3379

40. Kelbauskiene S, Maciulskiene V. A pilot study of Er,Cr:YSGG laser therapy used as an adjunct to scaling and root planing in patients with early and moderate periodontitis. Stomatologija. 2007;9(1):21-6. 